\title{
Poor sensitivity of rapid tests for the detection of antibodies to the hepatitis B virus: implications for field studies
}

\author{
Helena Medina Cruz', Leticia de Paula Scalioni¹, Vanessa Salete de Paula², Juliana Custódio Miguel', \\ Kycia Maria Rodrigues do $\mathrm{O}^{3}$, Flavio Augusto Pádua Milagres ${ }^{4}$, Marcelo Santos $\mathrm{Cruz}^{5}$, \\ Francisco Inácio Bastos ${ }^{6}$, Priscila Pollo Flores ${ }^{7}$, Erotildes Leal ${ }^{8}$, Ana Rita Coimbra Motta-Castro ${ }^{9}$, \\ Lia Laura Lewis-Ximenez ${ }^{1}$, Elisabeth Lampe', Livia Melo Villar ${ }^{1 /+}$
}

${ }^{1}$ Fundação Oswaldo Cruz-Fiocruz, Instituto Oswaldo Cruz, Laboratório de Hepatites Virais, Rio de Janeiro, RJ, Brasil

${ }^{2}$ Fundação Oswaldo Cruz-Fiocruz, Instituto Oswaldo Cruz, Laboratório de Desenvolvimento Tecnológico em Virologia, Rio de Janeiro, RJ, Brasil ${ }^{3}$ Hospital São Lucas, Petrópolis, RJ, Brasil

${ }^{4}$ Universidade Federal do Tocantins, Faculdade de Medicina, Palmas, TO, Brasil

${ }^{5}$ Universidade Federal do Rio de Janeiro, Instituto de Psiquiatria, Rio de Janeiro, RJ, Brasil

${ }^{6}$ Fundação Oswaldo Cruz-Fiocruz, Instituto de Comunicação e Informação Científica e Tecnológica em Saúde, Rio de Janeiro, RJ, Brasil

${ }^{7}$ Universidade de Brasília, Brasília, DF, Brasil

${ }^{8}$ Universidade Federal do Rio de Janeiro, Campus Macaé, Macaé, RJ, Brasil

${ }^{9}$ Universidade Federal do Mato Grosso do Sul, Departamento de Bioquímica e Farmácia, Campo Grande, MS, Brasil

Rapid tests (RTs) can be used as an alternative method for the conventional diagnosis of hepatitis B virus (HBV). This study aims to evaluate antibodies to HBsAg (anti-HBs) and antibodies to HBeAg (anti-HBe) RTs under different Brazilian settings. The following three groups were included: GI: viral hepatitis outpatient services; GII: low resource areas; and GIII: crack users and beauticians. Imuno-rápido anti-HBsAg ${ }^{\mathrm{TM}}$ and Imuno-rápido anti- $\mathrm{HBe}^{\mathrm{TM}}$ RTs were evaluated and showed specificities greater than $95 \%$ in all groups. The sensitivity values to anti-HBs were $50.38 \%, 51.05 \%$ and $46.73 \%$ and the sensitivity values to anti-HBe were $76.99 \%, 10.34 \%$ and $11.76 \%$ in the GI, GII and GIII groups, respectively. The assays had a low sensitivity and high specificity, which indicated their use for screening in regions endemic for HBV.

Key words: hepatitis B virus - antibodies - rapid tests - performance

Approximately 240 million individuals are chronically infected with hepatitis B virus (HBV) worldwide. Annually, 780,000 people die due to late-stage complications, such as cirrhosis and hepatocellular carcinoma (WHO 2015). In Brazil, between 2000 and 2012, 120,343 confirmed HBV cases were reported (BMH 2015). HBsAg prevalence is $0.63 \%$ in the north region, $0.31 \%$ in the midwest region and $0.31 \%$ in the southeast region (BMH 2015). Additionally, HBsAg prevalence among different groups (children, beauticians and crack users) is low ( $0 \%$ to $6.2 \%$ ) in Rio de Janeiro (Santos-Cruz et al. 2013, Villar et al. 2014a, b).

During HBV infection, markers can be detected in sera samples using immunoassays. For example, patient sera that contain anti-HBs indicates immunity from past infections or vaccinations, and a patient with anti-HBe antibodies in their sera is considered as spontaneous resolution of infection or therapy-induced improvement (Gerlich 2013, Villar et al. 2015).

A diagnosis of HBV is done using enzyme immunoassays (EIAs) and electrochemiluminescence (ECLIA) (Gerlich 2013, Villar et al. 2015). However, the use of these

doi: 10.1590/0074-02760160394

Financial support: FAPERJ, CNPq, CAPES, FIOCRUZ.

+ Corresponding author: Ivillar@ioc.fiocruz.br

Received 28 August 2016

Accepted 24 November 2016 assays in real-life conditions in low and middle-income countries has been challenging due to the relatively long period of execution, the necessity of well-trained personnel, good infrastructure and logistics (Soeung et al. 2009).

RTs are simple, easy, cheap and fast. Currently, several commercial RTs for HBsAg detection are available in Brazil, and $\mathrm{BMoH}$ has established policies and guidelines for HBsAg RT use (BMH 2016). The application of RTs as a substitute for conventional diagnoses of HBV infection may provide distinct advantages. Results are available in a few minutes, and RT use is feasible in poor infrastructure laboratories. HBsAg testing has shown high sensitivity, but some assays did not detect this marker, especially in low endemicity regions, such as Latin America. In these settings, it is recommended that additional HBV testing should be utilised for detecting other serological markers. Currently, few laboratories use RTs for other HBV markers, such as anti-HBs and anti-HBe. These assays could increase the identification of susceptible individuals for HBV vaccination and help in monitoring treatment response. Thus, in the present study, we evaluated the applicability of RTs for the detection of anti-HBs and anti-HBe markers in different groups to increase the availability of diagnosis in remote areas.

All individuals or parents/legal guardians signed the informed consent approved by the Ethics Committee of FIOCRUZ before recruitment. Serum samples were obtained from February 2009 to September 2013 from subjects who represented the following: 
Group I (GI) - Consisted of 423 and 166 individuals who donated serum samples for the anti-HBs and anti$\mathrm{HBe}$ RT evaluations, respectively. Individuals were referred from Viral Hepatitis Ambulatory (Oswaldo Cruz Foundation, FIOCRUZ). These individuals had suspected cases of viral hepatitis, and most of them lived in low socioeconomic areas in Rio de Janeiro state. Individuals were included if they were 18 years old or older, presented with either symptomatic or asymptomatic hepatitis, and had one or more risk factors for HBV infection.

Group II (GII) - Contained 1,526 and 788 individuals who donated serum samples for the anti-HBs and anti-HBe RT evaluations, respectively. These individuals lived in the following regions in Brazil: (1) Midwest Region - individuals from Pantanal of Mato Grosso do Sul state, a rural area $385 \mathrm{~km}$ from the capital of state, Campo Grande City; (2) North Region - subjects from rural communities in the city of Tocantinópolis in Tocantins state, $30 \mathrm{~km}$ from the urban area of the city; and (3) Southeast Region - employees from a private hospital located in Petrópolis and subjects living in an underprivileged community in Macaé (both cities in Rio de Janeiro). Individuals were included if they were not previously diagnosed as HBV infected.

Group III (GIII) - Consisted of 381 and 241 individuals who donated serum samples for the anti-HBs and antiHBe RT evaluations, respectively. This group of individuals was considered to be highly vulnerable individuals (crack users in the southeast region of Brazil and beauty professionals in Rio de Janeiro state) likely to acquire or already have an HBV infection. Individuals included in this group were active crack users and beauticians, including manicurists, pedicurists, and hairdressers.

Sera samples were assayed for $\mathrm{HBsAg}$, anti-HBc total, anti-HBc IgM and anti-HBs using commercial EIAs (Diasorin, Italy) and anti-HBe and $\mathrm{HBeAg}$ using commercial ECLIA (Elecsys anti-HBe and $\mathrm{HBe}$, Roche Diagnostics, Mannheim, Germany) according to the manufacturer's instructions. The $\mathrm{OD} / \mathrm{CO}$ of positive/negative samples was defined according to the manufacturer for each test. All reactive samples were retested using the same assay in duplicate.

Both Imuno-rápido anti-HBsAg ${ }^{\mathrm{TM}}$ and Imuno-rápido anti-HBeAg ${ }^{\mathrm{TM}} \mathrm{RTs}$ were evaluated (Wama, Minas Gerais, Brazil). According to the manufacturer's instructions, the assays had $100 \%$ sensitivity and more than $98 \%$ specificity. These RTs were single-use, disposable-chamber, in vitro, qualitative, immunochromatographic assays that could detect anti-HBs and anti-HBe. The RTs allowed the detection of antibodies in serum, plasma and whole blood and used $100 \mu \mathrm{L}$ of sample per assay. Each assay was completed in 10-15 min. Assays were conducted according to the manufacturer's recommendations.

The sensitivity of the anti-HBs RT was also evaluated in the following two additional subgroups: (1) vaccinated individuals (isolated anti-HBs reactive) and previously HBV infected (anti-HBs/anti-HBc reactive) and (2) individuals with anti-HBs titers lower than $100 \mathrm{IU} / \mathrm{mL}$ and titers higher than $100 \mathrm{IU} / \mathrm{mL}$. These cutoff values were chosen because approximately $85 \%$ of individuals who presented anti-HBs titers above $100 \mathrm{IU} / \mathrm{mL}$ after primary vaccination still had anti-HBs 22 years after vaccination.

The sensitivity of the anti-HBe RT was evaluated using the presence of an active HBV infection (anti-HBe reactive/HBsAg reactive), compared to a previous $\mathrm{HBV}$ infection (anti-HBe reactive/HBsAg non-reactive).

The detection of anti-HBs and anti-HBe in the serum samples by EIA or ECLIA was defined in the present study as the gold standard for the assessment of the sensitivity, specificity, positive predictive value (PPV), and negative predictive value (NPV) of each RT. To evaluate the deviation between the observed and expected values in each group, the $\mathrm{X}^{2}$ test or Fisher's exact test were used. The Kappa coefficient (k) was used to assess the degree of agreement between the reference panel and the RT under analysis. Two-tailed $p$-values $<0.05$ were considered statistically significant.

In this study, 2,330 individuals donated serum samples for the anti-HBs RT evaluation. The mean age \pm standard deviation was $48( \pm 13.99)$ years, 29 $( \pm 20.39)$ years and $33( \pm 14.41)$ years for GI, GII and GIII, respectively. Anti-HBs EIA for GI, GII and GIII showed 133, 572 and 107 reactive results, respectively, and 290, 954 and 274 non-reactive results, respectively. The sensitivity of the anti-HBs RT was relatively low in all groups, but a higher sensitivity was found in GII: $51.05 \%$ (292/572) compared to GI: $50.38 \%(67 / 133)$ and GIII: $46.73 \%$ (50/107). The specificity values were above $98.00 \%$ for all groups, and the concordance ranged from $53.32 \%$ to $57.66 \%$ in all groups (Table I).

Samples that presented a false-negative result for anti-HBs in RT had low mean optical density/cut-off value ratio $(\mathrm{OD} / \mathrm{CO})$ values by ELISA compared to those samples considered anti-HBs true positive samples (Table II). Better sensitivity results of anti-HBs RT were observed in samples previously infected with HBV compared to vaccinated individuals in all groups and samples with anti-HBs titers higher than $100 \mathrm{IU} / \mathrm{mL}$ compared to titers lower than $100 \mathrm{IU} / \mathrm{mL}$ in all groups (Table III).

A total of 1,195 individuals were included in the antiHBe RT evaluation. The mean age \pm standard deviation was $45.3( \pm 14.6)$ years, $31.6( \pm 20.7)$ years, $30.4( \pm 12.7)$ years for GI, GII and GIII, respectively. Anti-HBe results by ECLIA for GI, GII and GIII showed 113, 87 and 17 reactive results and 53, 701 and 224 non-reactive results, respectively. The sensitivities were $76.99 \%(87 / 111)$ in GI, $11.76 \%$ (2/17) in GIII and 10.34\% (9/87) in GII. Specificity values were above $95.00 \%$ for all groups, and a high concordance between anti-HBe RT and EIA was observed in GI $(\mathrm{k}=65.36 \%)$ (Table I).

False negative anti-HBe samples by anti-HBeAg RT presented higher mean $\mathrm{OD} / \mathrm{CO}$ values by ECLIA compared to the true positive anti-HBe samples (Table II). The anti-HBe RT also had a higher sensitivity in those individuals who presented active HBV infection compared to those who were previously infected (Table III).

RTs are useful tools for HBV screening in low resource areas and/or emergency settings, but limited studies have been conducted to evaluate the performance of RTs for anti-HBe (El-Ghitany \& Farghaly 2013) and anti-HBs (Oh et al. 1999, Whang \& Um 2005, Cha et al. 2006, Bottero 


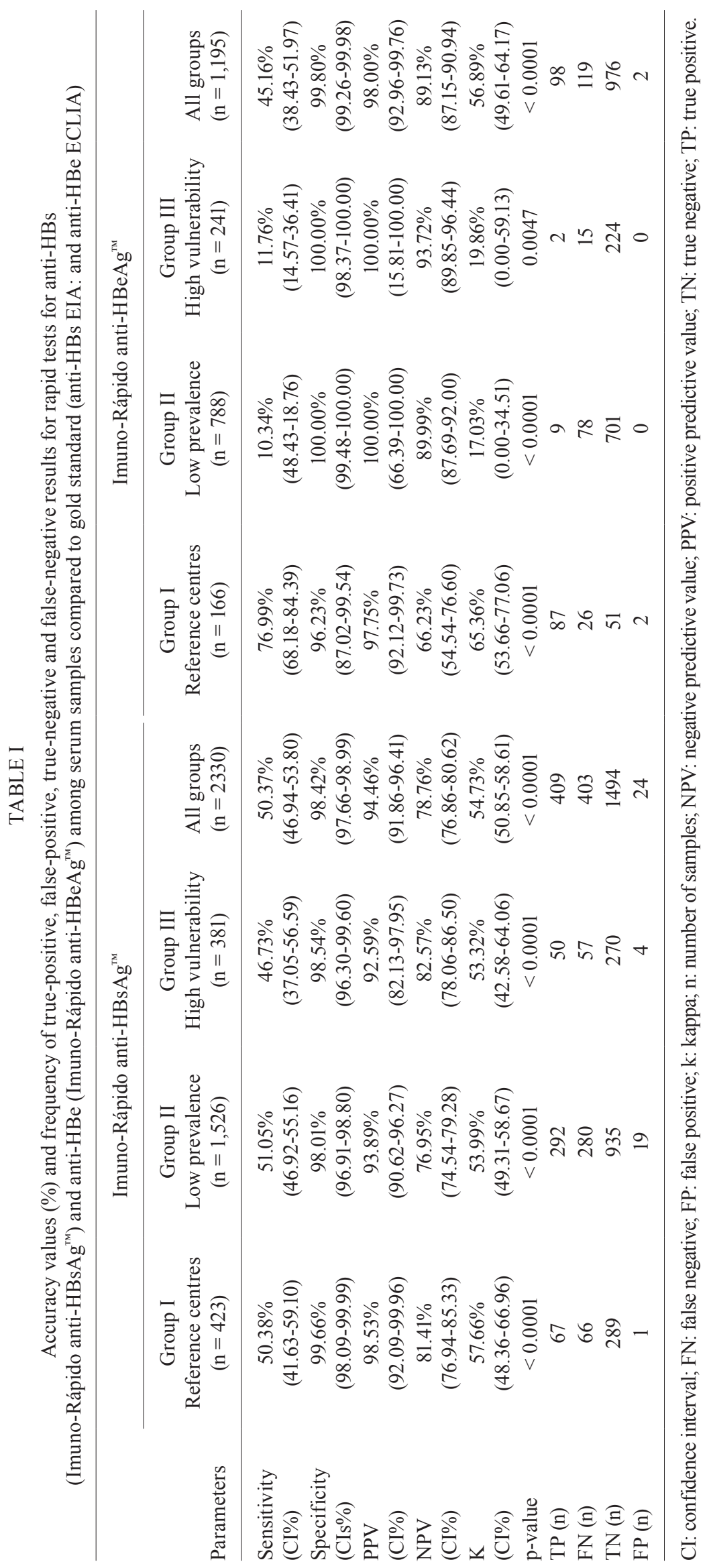


TABLE II

Mean values of $\mathrm{OD} / \mathrm{CO}$ from EIE among false-negatives and true positive rapid tests for anti-HBs and anti-HBe detection

\begin{tabular}{|c|c|c|c|c|c|c|}
\hline \multirow[b]{2}{*}{ Group } & \multicolumn{3}{|c|}{ Imuno-Rápido anti-HBsAg ${ }^{\mathrm{TM}}$} & \multicolumn{3}{|c|}{ Imuno-Rápido anti-HBeAg ${ }^{\mathrm{TM}}$} \\
\hline & $\begin{array}{c}\text { Anti-HBs FN } \\
\text { OD/CO mean } \pm \text { SD }\end{array}$ & $\begin{array}{c}\text { Anti-HBs TP } \\
\text { OD/CO mean } \pm \text { SD }\end{array}$ & p-value & $\begin{array}{c}\text { Anti-HBe FN } \\
\text { OD/CO mean } \pm \text { SD }\end{array}$ & $\begin{array}{c}\text { Anti-HBe TP } \\
\text { OD/CO mean } \pm \text { SD }\end{array}$ & p-value \\
\hline $\begin{array}{l}\text { Group I } \\
\text { Reference centres }\end{array}$ & $5.91 \pm 5.44$ & $29.56 \pm 22.84$ & $\mathrm{p}<0.0001$ & $0.264 \pm 0.316$ & $0.025 \pm 0.122$ & $\mathrm{p}<0.0001$ \\
\hline $\begin{array}{l}\text { Group II } \\
\text { Low prevalence }\end{array}$ & $5.00 \pm 6.46$ & $35.21 \pm 24.87$ & $\mathrm{p}<0.0001$ & $0.370 \pm 0.357$ & $0.099 \pm 0.282$ & $\mathrm{p}=0.0006$ \\
\hline $\begin{array}{l}\text { Group III } \\
\text { High vulnerability }\end{array}$ & $10.76 \pm 8.98$ & $30.60 \pm 27.23$ & $\mathrm{p}<0.0001$ & $0.349 \pm 0.422$ & $0.005 \pm 0.001$ & $\mathrm{p}=0.1791$ \\
\hline All groups & $6.03 \pm 7.02$ & $33.67 \pm 24.90$ & $\mathrm{p}<0.0001$ & $0.347 \pm 0.357$ & $0.032 \pm 0.142$ & $\mathrm{p}<0.001$ \\
\hline
\end{tabular}

FN: false negative; OD/CO: optical density/cutoff; SD: standard deviation; TP: true positive.

TABLE III

Sensitivity of the anti-HBs rapid test (Imuno-Rápido anti-HBsAg ${ }^{\mathrm{TM}}$ ) according to the anti-HBs titer and HBV status and sensitivity of anti-HBe rapid test (Imuno-Rápido anti-HBeAg ${ }^{\mathrm{TM}}$ )

\begin{tabular}{|c|c|c|c|c|c|c|}
\hline \multirow[b]{3}{*}{ Evaluated groups } & \multicolumn{4}{|c|}{ Anti-HBs } & \multirow{2}{*}{\multicolumn{2}{|c|}{$\begin{array}{c}\text { Anti-HBe } \\
\begin{array}{c}\text { Sensitivity of anti-HBe rapid test } \\
\text { according to HBV status }\end{array}\end{array}$}} \\
\hline & \multicolumn{2}{|c|}{$\begin{array}{l}\text { Sensitivity of anti-HBs rapid test } \\
\text { according to HBV status }\end{array}$} & \multicolumn{2}{|c|}{$\begin{array}{l}\text { Sensitivity of anti-HBs rapid test } \\
\text { according to anti-HBs titer }\end{array}$} & & \\
\hline & $\begin{array}{l}\text { Previously, HBV } \\
\text { infected }^{\mathrm{a}} \\
\mathrm{n}(\%)\end{array}$ & $\begin{array}{c}\text { HBV } \\
\text { vaccination }^{\mathrm{b}} \\
\mathrm{n}(\%)\end{array}$ & $\begin{array}{l}\text { anti-HBs titers } \\
<100 \mathrm{IU} / \mathrm{mL} \\
\mathrm{n}(\%)\end{array}$ & $\begin{array}{l}\text { anti-HBs titers } \\
\geq 100 \mathrm{IU} / \mathrm{mL} \\
\mathrm{n}(\%)\end{array}$ & $\begin{array}{l}\text { Active HBV } \\
\text { infection } \\
\mathrm{n}(\%)\end{array}$ & $\begin{array}{l}\text { Previously, } \\
\text { HBV infection } \\
\text { n }(\%)\end{array}$ \\
\hline $\begin{array}{l}\text { Group I } \\
\text { Reference centres }\end{array}$ & $28 / 47(59.57)$ & $39 / 86(45.35)$ & $7 / 51(13.72)$ & $60 / 82(73.17)$ & $84 / 100(84.00)$ & $3 / 13(23.10)$ \\
\hline $\begin{array}{l}\text { Group II } \\
\text { Low prevalence }\end{array}$ & $134 / 176(76.14)$ & $158 / 396(39.90)$ & 40/268 (14.92) & $252 / 304(82.89)$ & $1 / 1(100.00)$ & 8/86 (9.30) \\
\hline $\begin{array}{l}\text { Group III } \\
\text { High vulnerability }\end{array}$ & $15 / 18(83.33)$ & $35 / 89(39.32)$ & $2 / 41(4.87)$ & $48 / 66(72.72)$ & $1 / 3(33.30)$ & 1/14 (7.10) \\
\hline All groups & $177 / 241(73.44)$ & $232 / 571(40.63)$ & 49/360(13.61) & $360 / 452(79.65)$ & 86/104 (80.77) & 12/113 (10.62) \\
\hline
\end{tabular}

$a$ : anti-HBs/anti-HBc reactive; $b$ : anti-HBs alone; $c$ : anti-HBe reactive /HBsAg reactive; $d$ : anti-HBe reactive/HBsAg non-reactive; IU: international units; $\mathrm{n}$ : number of samples.

et al. 2013, 2016, El-Ghitany \& Farghaly 2013, Wu et al. 2016). In the present study, two RTs (Imuno-Rápido anti$\mathrm{HBeAg}^{\mathrm{TM}}$ and Imuno-Rápido anti-HBsAg ${ }^{\mathrm{TM}}$ ) were evaluated and showed high specificity and low sensitivities regardless of the endemicity profile of the populations analysed.

Anti-HBs RT showed high specificity values regardless of the endemicity profile of the populations evaluated and had similar values as those observed in France (97.80\%), Taiwan (96.5\%) and Egypt (95.08\%) (Bottero et al. 2013, El-Ghitany \& Farghaly 2013, Wu et al. 2016). These assays demonstrate an ability to identify true negative samples. Additionally, the sensitivity of anti-HBs RT was low in all groups (less than 51.5\%), which is similar to what was observed using whole blood with Quick Profile (Lumiquick, USA) (58.08\%) and sera samples with Advanced Test Quality One Step (Intec Products, China) (64.20\%) (Bottero et al. 2013, El-Ghitany \& Farghaly
2013). Furthermore, some studies have shown that the test sensitivity is above 91\% in volunteers and children (Bottero et al. 2016, Wu et al. 2016), and a meta-analysis study showed a pooled sensitivity and specificity of $93.2 \%$ and $93.1 \%$, respectively. However, RTs from different manufacturers were evaluated in those studies (General Biologicals Corporation, Genedia, Daewoong, Asan, Lumiquick diagnostics, and SD) (Shivkumar et al. 2012).

An interesting finding was the high sensitivity of the anti-HBs RT when samples with high values of OD/CO in EIE or high antibody titers (above $100 \mathrm{IU} / \mathrm{mL}$ ) were used. The sensitivity of these anti-HBs RTs was the same as previously described (El-Ghitany \& Farghaly 2013, Wu et al. 2016), showing that these tests may be useful for screening individuals with a high reactivity for antiHBs. The RT for anti-HBs detection also demonstrated better performance in individuals with previous infec- 
tions compared to individuals with a vaccine response. This difference may be due to the low anti-HBs titers obtained by vaccination in different circumstances, including immunosuppression, liver disease, renal failure, smoking, obesity, improper vaccine administration, short time interval between the second and third dose, age of the subject when vaccinated and the progressive decline of antibody titers in a large proportion of most individuals 9-11 years after vaccination (Kwon \& Lee 2011).

In agreement with previous studies, anti-HBs RT and anti-HBe RT also demonstrated high specificity (above $96.00 \%$ ) in all groups analysed, demonstrating an ability to discriminate negative results. The best performance of the anti-HBe RT was observed among patients referred to the Viral Hepatitis Clinic (65.36\%) demonstrating the usefulness of this assay in the evaluation of seroconversion of $\mathrm{HBeAg}$ to anti-HBe in patients who have HBV. This is a favorable outcome that might be associated with a better prognosis among HBV patients according to the guidelines issued by the BMH (2011).

The anti-HBe RT was highly effective when samples with HBV active infection or samples with low values of OD/CO by ECLIA were considered. Conversely, ElGhitany and Farghaly (2013) did not observe this finding which was probably due to differences in the RT and gold standard tests used.

In conclusion, RTs for anti-HBs and anti-HBe evaluated in the present study showed low sensitivity and high specificity indicating their use as a screening method in high HBV endemicity areas.

\section{ACKNOWLEDGEMENTS}

To Jaqueline Correia de Oliveira, Elisangela Ferreira da Silva, Renata Tourinho Santos and Paula Guerra Murat, for technical assistance.

\section{AUTHORS' CONTRIBUTION}

LMV conceived the study; LMV, HMC and EL designed the study protocol; KMRO, FAPM, MSC, FIB, PPF, ErL, ARCMC, LLLX carried out the clinical assessment, subject selection and recruitment; HMC, LPS, VSP, JCM, LMV performed the rapid tests, immunoassays, analysis and interpretation of these data; LMV, HMC drafted the manuscript; FIB, VSP, LMV, LLLX, EL critically revised the manuscript for intellectual content. All authors read and approved the final manuscript.

\section{REFERENCES}

BMH - Brazilian Ministry of Health. Clinical protocol and therapeutic guidelines for the treatment of chronic viral hepatitis B and coinfections. 2011. Available from: http://funed.mg.gov.br/wpcontent/ uploads/2011/07/prot_clinico_diretrizes_terapeuticas_hep_B.pdf.

BMH - Brazilian Ministry of Health. Epidemiological Bulletin - Viral Hepatitis. 2015. Available from: http://www.aids.gov.br/sites/ default/files/anexos/publicacao/2015/58210/_p_boletim_hepatites_final_web_pdf_p_16377.pdf.

BMH - Brazilian Ministry of Health. Include procedures concerning rapid tests for detection of hepatitis B virus infection - HBV in table of procedures, drugs, orthotics, prosthetics and spe- cialty materials for SUS. Ordinance $\mathrm{n}^{\circ} 828$ from 2016-07-05. 2016. Available from: http://www.lex.com.br/legis_27165116 PORTARIA_N_828_DE_5_DE_JULHO_DE_2016.aspx.

Bottero J, Boyd A, Gozlan J, Carrat F, Lemoine M, Rougier H, et al. Effectiveness of hepatitis B rapid tests toward linkage-to-care: results of a randomized, multicenter study. Eur J Gastroenterol Hepatol. 2016; 28(6): 633-9.

Bottero J, Boyd A, Gozlan J, Lemoine M, Carrat F, Collignon A, et al. Performance of rapid tests for detection of HBsAg and antiHBsAb in a large cohort, France. J Hepatol. 2013; 58(3): 473-8.

Cha YJ, Yang JS, Chae SL. Evaluation of indigenously manufactured immunochromatographic assay systems for rapid detection of hepatitis B surface antigen and antibody. Korean J Lab Med. 2006; 26(1): 52-7.

El-Ghitany EM, Farghaly AG. Evaluation of commercialized rapid diagnostic testing for some Hepatitis B biomarkers in an area of intermediate endemicity. J Virol Methods. 2013; 194(1-2): 190-3.

Gerlich WH. Medical virology of hepatitis B: how it began and where we are now. Virol J. 2013; 10: 239.

Kwon SY, Lee CH. Epidemiology and prevention of hepatitis B virus infection. Korean J Hepatol. 2011; 17: 87-95.

Oh J, Kim TY, Yoon HJ, Min HS, Lee HR, Choi TY. Evaluation of Genedia HBsAg rapid and Genedia anti-HBs rapid for the screening of HBsAg and anti-HBs. Korean J Clin Pathol. 1999; 19(1): 114-7.

Santos-Cruz M, Andrade T, Bastos FI, Leal E, Bertoni N, Villar LM, et al. Key drug use, health and socio-economic characteristics of young crack users in two Brazilian cities. Int J Drug Policy. 2013; 24: 432-8.

Shivkumar S, Peeling R, Jafari Y, Joseph L, Pai NP. Rapid point-ofcare first-line screening tests for hepatitis B infection: a metaanalysis of diagnostic accuracy (1980-2010). Am J Gastroenterol. 2012; 107(9): 1306-13.

Soeung SC, Rani M, Huong V, Sarath S, Kimly C, Kohei T. Results from nationwide hepatitis B serosurvey in Cambodia using simple and rapid laboratory test: implications for National Immunization Program. Am J Trop Med Hyg. 2009; 81(2): 252-7.

Villar LM, Amado LA, de Almeida AJ, de Paula VS, Lewis-Ximenez LL, Lampe E. Low prevalence of hepatitis $\mathrm{B}$ and $\mathrm{C}$ virus markers among children and adolescents. Biomed Res Int. 2014a; 2014: 324638.

Villar LM, Cruz HM, Barbosa JR, Bezerra CS, Portilho MM, Scalioni LP. Update on hepatitis B and C virus diagnosis. World J Virol. 2015; 4(4): 323-42.

Villar LM, de Paula VS, de Almeida AJ, do Ó KM, Miguel JC, Lampe E. Knowledge and prevalence of viral hepatitis among beauticians. J Med Virol. 2014b; 86(9): 1515-21.

Whang D, Um T. Comparison of immunochromatographic assays and quantitative immunoassays for detecting HBsAg and anti-HBs. Korean J Lab Med. 2005; 25: 186-91.

WHO - World Health Organization. Hepatitis B. 2015. Available from: http://www.who.int/mediacentre/factsheets/fs204/en/.

Wu FY, Liao YW, Wu JF, Chen HL, Hsu HY, Chang MH, et al. A simple and rapid test-card method to detect hepatitis B surface antigen and antibody: potential application in young children and infants. Pediatr Neonatol. 2016; 57(3): 219-24. 